\title{
USING OF TRADITIONAL AND QUANTITATIVE CYTOCHEMICAL METHODS FOR IDENTIFICATION AND ENZYME CHARACTERIZATION OF SOME E.COLI SEROGROUPS CAUSING ENTERITIS IN BUFFALOES
}

\author{
HELAL, A.D. ; HANAN, E.NAGIB ${ }^{* *}$; ABDEL-SAMEA, M.E. ${ }^{* * *}$ and ABDEL-FATTAH, SH.M. ${ }^{* * * *}$ \\ ${ }^{*}$ Animal Health Research Institute (Banha branch, Biochem.Dept.) \\ ${ }^{* *}$ Animal Health Research Institute (Buffalo Dept., Bacteriology) \\ ${ }^{* * *}$ Animal Health Research Institute (Aswan branch, Biochem. Dept.) \\ ***** National Research Center (Nutritional toxin Dept.) \\ Email: hnaguib990@yahoo.com
}

\section{ABSTRACT}

Received at: 1/6/2014

Accepted: 11/8/2014
Enteritis is most fatal disease especially for neonatal and young buffalo calves. Out of 150 fecal samples, 100 from diarrheic and 50 from non diarrheic (apparently healthy) buffalo calves were collected from private farms for isolation and identification of E.coli using morphological, cultural, biochemical and serological examination. Further cytochemical enzyme characterization of the different identified serogroups were carried out through the cytochemical quantitative determination of bacterial mitochondrial Adenosene-tri phosphatase (ATP-ase) and succinic dehydrogenase (SDH-ase) enzyme activities for their possible variations among the isolated and identified E.coli serogroups. Four values to each of E.coli serogroup ( 2 for each enzyme) as optical densities (OD.) could be obtained : (ATPase activity \& Actual ATP-ase reaction and SDH-ase activity \& Actual SDH-ase reaction) for E.coli-serogroups: E.coli $\mathrm{O}_{26}$, E.coli $\mathrm{O}_{55}$, E.coli $\mathrm{O}_{78}$, E.coli $\mathrm{O}_{86}$ and E.coli $\mathrm{O}_{111}$ as following: (0.595 \& 0.285 and $\left.0.560 \& 0.210\right),(0.565 \& 0.265$ and $0.550 \& 0.200),(0.590 \& 0.255$ and $0.540 \& 0.190),(0.590 \& 0.205$ and $0.490 \&$ $0.180)$ and $(0.600 \& 0.160$ and $0.560 \& 0.150) \mathrm{nm}$ respectively. It was observed that the SDH-ase enzyme activity differentiate between the majority of the studied E.coli-serogroups for the significant $(\mathrm{P} \leq 0.05)$ variations between their enzyme activities (except between the serogroups E.coli $\mathrm{O}_{26}$ and E.coli $\mathrm{O}_{111}$ which showed the same (non-significant) SDH-ase activity, but ATP-ase enzyme activity could not differentiate between the different E.coli serogroups because of its non-significant variations among different serogroups (except with the serogroup E.coli $\mathrm{O}_{55}$ which showed the significant lower ATP-ase enzyme activity and noted to be lower pathogenic than the other E.coli serogroups), so that the actual ATP-ase enzyme activities (the difference between the OD. after and before incubation period) may be used for differentiation between different serogroups. Further cytochemical characterization to other bacterial enzymes and to other E.coli serogroups should be carried out as additional tool for a definite differentiation and characterization of E.coli serogroups causing enteritis in buffalo calves.

Keywords: E.coli serogroups, diarrhea, cytochemical examination, bacterial ATP-ase and bacterial SDH-ase

\section{INTRODUCTION}

Diarrhea is a predominant cause of mortality in neonatal buffalo calves leading to significant economic losses Rana et al. (2012). A key role in the etiology of bacterial infectious diarrhea in buffalo calves has been attributed to enteropathogenic E.coli mainly during the first three weeks of life Zaman et al. (2006). The pathogenic E.coli adhere to the mucosa and proliferate in the lumen of intestine, producing a potent enterotoxin, which stimulate excessive secretion of fluid from intestinal mucosa.
This loss of fluid causes the principle sign (diarrhea) and often leads to dehydration and high rate of death in the buffalo calves and consequently causes heavy economic losses Radostits et al. (1994). E.coli produces septicemia and diarrhea in a wide range of hosts including man, poultry and animals such as cattle, piglets, kids, foals, lambs and buffaloes Paul et al. (2010). Bacteraemia can rapidly lead to death or infection in different organs such as in the meninges, joints or eyes. In addition to economic losses, diarrhea in livestock is important because of the public health implications Tevejo et al. (2005). To be 
able to trace reliably the source and mode of transmission of an outbreak, an epidemiological typing method must be able to discriminate reproducibly between different strains and identify identical strains. Virulence in microorganisms is associated with the capacity to attach and colonize at the site of infection, with subsequent damage to the host and is promoted by aggressins that interfere with the host defense Burrows (1985). Various studies indicate that pathogenic E.coli cause diarrheal diseases either by invasion of intestinal mucosa after attachment to host epithelial cells through pili or by elaboration of enterotoxins Giannella (1976).

It could be reported that virulent E.coli strains carried alpha hemolysin determinants and suggested that hemolysins might play a role in the pathogenicity of E.coli by releasing iron required for bacterial growth, by killing the host defense cells, or by there cytotoxic effects on kidney cells Cavalieri et al. (1984). Most strains of E.coli are harmless, saprophytes, however, some are pathogenic by virtue of plasmid mediated virulence factors through which disease is induced Janke et al. (1990). The quantitative estimation of $\mathrm{Mg}^{+2}$ activated ATP-ase determined in E.coli suspension through determining the amount of phosphate released colorimetrically (Butling et al., 1973; raw, 1975; Helal et al., 2011 and Helal et al., 2013). Also previous trials of quantitative cytochemical determination of succinic dehydrogenase (SDH-ase) enzyme activity in Bacillus megaterium through determining the optical density of the end reaction product (formazan pigment) spectrophotometrically Hess and Dietrich, (1960). A recent trial for identification different strains of Brucella organisms compared to other bacterial species (Salmonella Dublin, E.coli $\mathrm{O}_{157} \mathrm{H}_{7}$ and Plesiomonas shigelliodes) through quantitative cytochemical estimation of ATP-ase and SDH-ase enzyme activities in their suspensions (with fixed concentration of $5 \times 10^{6} \mathrm{CFU} / \mathrm{ml}$ ). The study could obtained significantly different optical densities for each of the two enzymes (after one hour incubations with their specific substrates) and there were a reverse relationship between the calculated actual enzyme activities of the two enzymes Helal et al. (2011). Also another recent semular trial for cytochemical characterization of ATP-ase and SDHase enzymes for identification of bacteria causing mastitis Helal et al. (2013). The objective of this work is to isolate and identify some E.coli serogroups associated with buffalo calf diarrhea by traditional bacteriological methods with investigation of some important virulence factors associated with such isolates and used such isolates for additional cytochemical enzyme characterization for some bacterial enzymes as first trial for identification and differentiation between the serogroups of same species (E.coli) that causing enteritis in buffalo calves.

\section{MATERIALS and METHODS}

\section{1- Collection of samples:}

A total of 150 fecal samples were collected from buffalo calves 3 to 6 weeks of age (100 were diarrheic and 50 were non diarrheic).

These buffaloes were obtained from private farms in Cairo and Giza governorates. Aliquots of $5 \mathrm{~g}$ of rectal feces were separately collected using sterile disposable plastic gloves that were inverted after sampling. Samples were transferred to the laboratory in a cold chamber container to be cultured as soon as possible.

\section{2- Isolation and identification of E.coli strains:}

Fecal samples were primarily cultured on MacConkey agar medium, incubated aerobically at $37^{\circ} \mathrm{C}$. After an overnight incubation, apart of single typical well isolated lactose fermenting colony was tested for sorbitol fermentation by culturing on sorbitol MacConkey agar and sorbitol phenol red agar media, then incubated at $37^{\circ} \mathrm{C}$ overnight. Morphological, cultural and biochemical examinations were carried out according to Quinn et al. (1994).

\section{3- Serological identification of $\boldsymbol{E}$.coli isolates:}

Antisera of E.coli were used for serological identification of somatic antigen 'O' using slide agglutination test according to Koneman et al. (1997). The E.coli immune-O-sera (polyvalent sera), 8 vials and Monovalent sera, 43 vials also, were obtained from Denka Seiken Co. LTD, Tokyo, Japan.

\section{4-Detection of virulence factors of $E$.coli isolates:}

4.1. Hemolytic activity (Hemolysin): was tested using 5\% defibrinated sheep blood agar Beutin et al. (1989).

4.2. Enterotoxin (STa) detection: The ability to produce heat stable enterotoxin was assayed by the infant mouse test Robins-Brown et al. (1993).

4.3. Invasiveness assay: The ability of E.coli isolates to invade epithelial cells were tested Janda and Abbott, (1998).

4.4. Verotoxin activity of $\boldsymbol{E}$.coli serovars: Detection of cytotoxin activity of E.coli strains isolated from the fecal samples using Vero cells Giugliano et al. (1982).

4.5. Congo red binding test: It's a test which differentiate between pathogenic and non pathogenic E.coli isolates Berkhoff and Vinal, (1986).

\section{Cytochemical identification of E.coli serogroups:}


5.1. Preparation of bacterial suspension of $5 \times 10^{6}$ CFU/ml concentration: Using aseptic techniques, a single colony from each of the isolated and previously identified E.coli serogroup was transformed into $100 \mathrm{ml}$ bottle of Iso-Sensitest broth incubated overnight at $35^{\circ} \mathrm{C}$, centrifugated at 4000 rpm for 5 minutes to obtain clean sample of bacterial suspension, concentrated bacterial suspensions were prepared in saline with optical density of $500 \mathrm{~nm}$, from which serial dilutions with saline were prepared until the optical density become in range of $0.750 \mathrm{~nm}$, the actual number of colony forming units was calculated from the viability graph, the dilution factor needed was calculated and the dilution was carried out to obtain a concentration of bacterial suspension of $5 \times 10^{6} \mathrm{CFU} / \mathrm{ml}$ Sarker et al. (2007).

5.2. Preparation of substrate incubation media for Adenosine triphosphatase (ATP-ase) enzyme ( $\mathrm{Mg}^{+2}$-activated, lead method):

According toWachstein and Meisel, (1957).

5.3. Preparation of succinate substrate medium for succinate dehydrogenase SDH-ase enzyme activity:

According to Nachlas et al. (1957).

5.4. Procedure for qautitative estimation of bacterial ATP-ase ( $\mathrm{Mg}^{+2}$-activated, lead method): Wachstein and Meisel, (1957):

5.4.1. In five clean, dry and sterile test tubes, put $1 \mathrm{ml}$ of bacterial suspension of certain E.coli serogroup of bacterial concentration of $5 \times 10^{6} \mathrm{CFU} / \mathrm{ml}$.

5.4.2. Add $1 \mathrm{ml}$ of substrate incubation medium for ATP-ase enzyme in each tube containing bacterial suspension, gentle mixing and recording the optical density (OD.) at wave length (wl) of $555 \mathrm{~nm}$ before incubation.

5.4.3. Incubate the mixture at $37^{\circ} \mathrm{C}$ for exactly 30 minutes, add $0.5 \mathrm{ml}$ of $1 \%$ ammonium sulfide solution (the color then become dark brown).
5.4.4. Dilute the mixture with $4.5 \mathrm{ml}$ normal saline with gentle mixing and directly record the OD. of the mixture spectrophotometrically at 555nm.wl according to Andreu et al. (1973).

5.4.5. The above procedure was repeated for each of the rest serogroups of E.coli.

5.5. Procedure for quantitative estimation of bacterial SDH-ase enzyme activity: Nachlas et al. (1957): The same procedures for ATP-ase estimation was followed for SHD-ase enzyme estimation in the five E.coli serogroups, except in case of SDH-ase, there was no dilution and no chemical added and the OD. was read at WL of $450 \mathrm{~nm}$.

5.6. The semi-quantitative cytochemical determination of ATP-ase and SDH-ase enzyme reactions in different E.coli serogroups: Put $0.7 \mathrm{ml}$ from specific substrate medium for each enzyme with the same volume of bacterial suspension (from each of E.coli serogroup) on clean dry and sterile glass slide, incubated at $37^{\circ} \mathrm{C}$ for 45 minutes. The SDH-ase reaction slides were counter-stained with $2 \%$ methylene blue, but the slides with ATP-ase reactions were added to it 4 drops of $1 \%$ ammonium.

Sulfide and then counterstained with safranin-O (1\%). All sides were dried and mounted with glycerol jelly and covered with cover slides to be examined microscopically with high power for ATP-ase or $\mathrm{SDH}$-ase enzyme reactions semi-quantitatively which ranged from trace to intense enzyme reactions according to the intensity of diformazan pigment or lead sulfide pigment for SDH-ase and ATP-ase enzyme reaction respectively according to Pearse (1972).

\subsection{Statistical Analysis:}

The optical denisities obtained from the enzymes reactions of the different E.coli serogroups were statistically evaluated using the Analysis of variance (ANOVA) according to Snedecor and Cochran, (1969).

\section{RESULTS}

Table 1: Percentage of E.coli from buffalo calves fecal samples.

\begin{tabular}{cccc}
\hline Source of isolates & No. of examined samples & No. of E.coli isolates & $\%$ \\
\hline Apparently healthy buffalo calves & 50 & 13 & 26 \\
\hline Diarrheic buffalo calves & 100 & 72 & 72 \\
\hline Total & 150 & 85 & 56.66 \\
\hline
\end{tabular}


Assiut Vet. Med. J. Vol. 60 No. 142 July 2014

Table 2: E.coli serogroupes isolated from apparently healthy buffalo calves.

\begin{tabular}{cccccc}
\hline Isolates & $\mathrm{O}_{26}$ & $\mathrm{O}_{111}$ & $\mathrm{O}_{78}$ & $\mathrm{O}_{55}$ & $\mathrm{O}_{86}$ \\
\hline No. & 5 & 3 & 2 & 2 & 1 \\
\hline$\%$ & 38.46 & 23.07 & 15.38 & 15.38 & 7.69 \\
\hline
\end{tabular}

The percentage of E.coli isolates in relation to apparently healthy buffalo calves (13)

Table 3: E.coli serogroupes isolated from diarrheic buffalo calves.

\begin{tabular}{cccccc}
\hline Isolates & $\mathrm{O}_{26}$ & $\mathrm{O}_{111}$ & $\mathrm{O}_{78}$ & $\mathrm{O}_{55}$ & $\mathrm{O}_{86}$ \\
\hline No. & 30 & 15 & 14 & 7 & 6 \\
\hline$\%$ & 41.66 & 20.83 & 19.44 & 9.72 & 8.33 \\
\hline
\end{tabular}

The percentage of E.coli isolates in relation to diarrheic buffalo calves (72).

Table 4: Virulence determinants of E.coli strains isolated from apparently healthy and diarrheic buffalo calves fecal samples.

\begin{tabular}{cccccccccccccc}
\hline $\begin{array}{c}\text { Virulence } \\
\text { Factors }\end{array}$ & \multicolumn{3}{c}{$\begin{array}{c}\text { Isolates from apparently } \\
\text { healthy buffalo calves }\end{array}$} & \multicolumn{7}{c}{ Isolates from diarrheic buffalo } & & Total \\
& & $\mathrm{O}_{26}$ & $\mathrm{O}_{111}$ & $\mathrm{O}_{78}$ & $\mathrm{O}_{55}$ & $\mathrm{O}_{86}$ & $\mathrm{O}_{26}$ & $\mathrm{O}_{111}$ & $\mathrm{O}_{78}$ & $\mathrm{O}_{55}$ & $\mathrm{O}_{86}$ & No. & $\%$ \\
& $(5)$ & $(3)$ & $(2)$ & $(2)$ & $(1)$ & $(30)$ & $(15)$ & $(14)$ & $(7)$ & $(6)$ & \\
\hline $\begin{array}{c}\text { Haemolytic } \\
\text { activity }\end{array}$ & 1 & 1 & 0 & 0 & 0 & 20 & 11 & 10 & 6 & 3 & 52 & 61.17 \\
\hline $\begin{array}{c}\text { Enterotoxin } \\
\text { Production }\end{array}$ & 0 & 0 & 0 & 0 & 0 & 0 & 8 & 10 & 5 & 3 & 26 & 30.58 \\
\hline $\begin{array}{c}\text { Verotoxin } \\
\text { Production }\end{array}$ & 1 & 0 & 1 & 1 & 0 & 20 & 0 & 10 & 5 & 3 & 41 & 48.23 \\
\hline $\begin{array}{c}\text { Invasiveness } \\
\text { Congo red } \\
\text { binding }\end{array}$ & 1 & 1 & 0 & 0 & 0 & 20 & 8 & 10 & 5 & 3 & 48 & 56.47 \\
\hline
\end{tabular}

The percentage was calculated in relation to the total number of the isolated E.coli strains (85)

The cytochemical study

\section{A- The ATP-ase enzyme activity of different E.coli serogroups:}

1- The optical densities (OD.) of ATP-ase before incubation period:

There were significant variations of the OD. of ATPase activitie between all E.coli serogroups.

2- The optical densities (OD.) of ATP-ase after incubation period:
There were no significant variation of the OD. of ATP-ase activities between E.coli serogroups (except between E.coli $\mathrm{O}_{55}$ and E.coli $\mathrm{O}_{111}$ which could be significantly differentiated from the other three groups) the highest ATP-ase activity showed by E.coli $\mathrm{O}_{55}$ (Table 5).

B-The SDH-ase enzyme activity of different E.coli serogroups:

1-The optical densities (OD.) of SDH-ase before incubation period: 
There were significant variations of the OD. of SDHase activities between all E.coli serogroups.

2-The optical densities (OD.) of SDH-ase after incubation period:

There were significant variations of the OD. of SDHase activities between different E.coli serogroups except E.coli $\mathrm{O}_{26}$ and E.coli $\mathrm{O}_{111}$ which could not differentiated between each other as they showed the same OD. value. The highest SDH-ase activity was showed by E.coli $\mathrm{O}_{26}$, but the lowest $\mathrm{SDH}$-ase activity was showed by E.coli $\mathrm{O}_{86}$ (Table 6).

\section{C- The Actual Enzymatic Reactions of ATP-ase and SDH-ase of E.coli serogroups:}

The actual enzyme reactions is the difference between the OD. of enzyme activity after and before the incubation period.

\section{1- Actual ATP-ase enzyme reaction:}

The actual ATP-ase enzyme activities of the different E.coli serogroups which arranged from highest to lowest reactions are 285,265,255,205 and $160 \mathrm{~nm}$ for E.coli $\mathrm{O}_{86}, \mathrm{O}_{78}, \mathrm{O}_{111}, \mathrm{O}_{26}$ and $\mathrm{O}_{55}$ respectively (Table 7).

\section{2- Actual SDH-ase enzyme reaction:}

The actual SDH-ase enzyme reactions of the different E.coli serogroups which arranged from highest to lowest reactions are $210,200,190,180$ and $150 \mathrm{~nm}$ for E.coli $\mathrm{O}_{111}, \mathrm{O}_{78}, \mathrm{O}_{86}, \mathrm{O}_{26}$ and $\mathrm{O}_{55}$ respectively (Table 7).

3- The Reverse Relationships between the percentages of the actual ATP-ase and SDH-ase reaction:

There is a reverse relationship between the percentages of the actual ATP-ase and the actual $\mathrm{SDH}$-ase enzyme reactions of E.coli serogroups (in relation to their higher actual enzyme reactions). Such reverse reactions between the percentages of the two enzymes of the different serogroups are recorded in Table (9) and illustrated in Fig. (1).

D- The semi-quantitative estimation of ATP-ase and SDH-ase enzyme reactions in different $E$.coli serogroups:

\section{1- ATP-ase activity:}

ATP-ase enzyme activities of the different E.coli serogroups ranged from moderate reactions $(+++)$ in E.coliO $_{55}$ to (strong to intense) reactions $(++++ \pm)$ in E.coliO $_{111}$ (Table10 and Fig. 2-A and 2-B).

\section{2- SDH-ase activity:}

The SDH-ase enzyme reactions of the different E.coli serogroups ranged from submoderate reactions $(++)$ in E.coliO $\mathrm{O}_{86}$ to strong reactions $(++++)$ in E.coliO $\mathrm{O}_{26}$ and E.coliO $\mathrm{O}_{111}$ (Table 10 and Fig. 2-C and 2-D).

Table 5: The quantitative estimation of Adenosine Tri-phosphatase (ATP-ase) bacterial enzyme activity of the different bacterial suspensions of the different serogroups (the concentration of the all bacterial suspensions $=5 \times 10^{6} \mathrm{CFU} / \mathrm{ml}$ at optical density (OD.) of $0.750 \mathrm{~nm}$ and $\left.\mathrm{WL}=0.750 \mathrm{~nm}\right)$.

\begin{tabular}{ccccccc}
\hline E.coli & $\begin{array}{c}\text { E.coli } \\
\mathrm{O}_{26}\end{array}$ & $\begin{array}{c}\text { E.coli } \\
\mathrm{O}_{55}\end{array}$ & $\begin{array}{c}\text { E.coli } \\
\mathrm{O}_{78}\end{array}$ & $\begin{array}{c}\text { E.coli } \\
\mathrm{O}_{86}\end{array}$ & $\begin{array}{c}\text { E.coli } \\
\mathrm{O}_{111}\end{array}$ & $\begin{array}{c}\text { LSD } \\
\text { (at P } \leq 0.005)\end{array}$ \\
\hline $\begin{array}{c}\text { OD. of ATP-ase before } \\
\text { incubation }\end{array}$ & $0.390^{\mathrm{a}}$ & $0.405^{\mathrm{b}}$ & $0.325^{\mathrm{c}}$ & $0.305^{\mathrm{d}}$ & $0.345^{\mathrm{e}}$ & 0.003 \\
& \pm 0.002 & \pm 0.001 & \pm 0.002 & \pm 0.001 & \pm 0.001 & \\
\hline OD. of ATP-ase after & $0.595^{\mathrm{ac}}$ & $0.565^{\mathrm{b}}$ & $0.590^{\mathrm{a}}$ & $0.390^{\mathrm{a}}$ & $0.600^{\mathrm{c}}$ & 0.010 \\
incubation & \pm 0.001 & \pm 0.019 & \pm 0.002 & \pm 0.002 & \pm 0.002 & \\
\hline
\end{tabular}

N.B.: the different litters in rows denote presence of significant differences between means (at $\mathrm{P} \leq 0.005$ ).

Table 6: The quantitative estimation of Succinate Dehydrogenase (SDH-ase) bacterial enzyme activities of the different E.coli serogroups bacterial suspensions (the concentration of the all bacterial suspensions $=5 \mathrm{X} 10^{6} \mathrm{CFU} / \mathrm{ml}$ at optical density (OD.) of $0.750 \mathrm{~nm}$ and $\mathrm{WL}=0.750 \mathrm{~nm}$ ).

\begin{tabular}{ccccccc}
\hline E.coli & $\begin{array}{c}\text { E.coli } \\
\mathrm{O}_{26}\end{array}$ & $\begin{array}{c}\text { E.coli } \\
\mathrm{O}_{55}\end{array}$ & $\begin{array}{c}\text { E.coli } \\
\mathrm{O}_{78}\end{array}$ & $\begin{array}{c}\text { E.coli } \\
\mathrm{O}_{86}\end{array}$ & $\begin{array}{c}\text { E.coli } \\
\mathrm{O}_{111}\end{array}$ & $\begin{array}{c}\text { LSD } \\
\text { (at } \mathrm{P} \leq 0.005)\end{array}$ \\
\hline OD. of SDH -ase before & $0.380^{\mathrm{a}}$ & $0.400^{\mathrm{b}}$ & $0.340^{\mathrm{c}}$ & $0.300^{\mathrm{d}}$ & $0.350^{\mathrm{e}}$ & 0.002 \\
incubation & \pm 0.002 & \pm 0.002 & \pm 0.001 & \pm 0.002 & \pm 0.002 & \\
\hline OD. of SDH -ase after & $0.560^{\mathrm{a}}$ & $0.550^{\mathrm{b}}$ & $0.540^{\mathrm{c}}$ & $0.490^{\mathrm{d}}$ & $0.560^{\mathrm{a}}$ & 0.003 \\
incubation & \pm 0.002 & \pm 0.002 & \pm 0.002 & \pm 0.002 & \pm 0.002 & \\
\hline
\end{tabular}

N.B.: the different litters in rows denote presence of significant differences between means (at $\mathrm{P} \leq 0.005$ ). 
Table 7: The actual reactions of ATP-ase and SDH-ase of the different E.coli serogroups (as difference between the OD. after and before (A-B) incubations and the values of actual reactions arranged from higher values).

\begin{tabular}{|c|c|c|c|c|c|}
\hline E.coli serogroups & $\begin{array}{c}\text { E.coli } \\
\mathrm{O}_{86}\end{array}$ & $\begin{array}{c}\text { E.coli } \\
\mathrm{O}_{78}\end{array}$ & $\begin{array}{c}\text { E.coli } \\
\mathrm{O}_{111}\end{array}$ & $\begin{array}{c}\text { E.coli } \\
\mathrm{O}_{26}\end{array}$ & $\begin{array}{c}\text { E.coli } \\
\mathrm{O}_{55}\end{array}$ \\
\hline Actual ATP-ase reaction & 285 & 265 & 255 & 205 & 160 \\
\hline E.coli serogroups & $\begin{array}{c}\text { E.coli } \\
\mathrm{O}_{111}\end{array}$ & $\begin{array}{c}\text { E.coli } \\
\mathrm{O}_{78}\end{array}$ & $\begin{array}{c}\text { E.coli } \\
\mathrm{O}_{86}\end{array}$ & $\begin{array}{c}\text { E.coli } \\
\mathrm{O}_{26}\end{array}$ & $\begin{array}{c}\text { E.coli } \\
\mathrm{O}_{55}\end{array}$ \\
\hline Actual of SDH-ase reaction & 210 & 200 & 190 & 180 & 150 \\
\hline
\end{tabular}

Table 8: The reverse relationships between the percentages of the actual ATP-ase and SDH-ase enzymes reactions of the E.coli serogroups in relation to the higher actual enzyme activities.

\begin{tabular}{lccccc}
\hline $\begin{array}{l}\text { Actual } \\
\text { enzyme reactions }\end{array}$ & $\begin{array}{c}\text { E.coli } \\
\mathrm{O}_{86}\end{array}$ & $\begin{array}{c}\text { E.coli } \\
\mathrm{O}_{78}\end{array}$ & $\begin{array}{c}\text { E.coli } \\
\mathrm{O}_{111}\end{array}$ & $\begin{array}{c}\text { E.coli } \\
\mathrm{O}_{26}\end{array}$ & $\begin{array}{c}\text { E.coli } \\
\mathrm{O}_{55}\end{array}$ \\
\hline ATP-ase $\%$ & 100 & 92.98 & 89.47 & 71.93 & 56.14 \\
\hline SDH-ase $\%$ & 90.48 & 95.24 & 100 & 85.71 & 71.43 \\
\hline
\end{tabular}

Table 9: The semi-quantitative estimation of ATP-ase and SDH-ase enzyme activities of different serogroups of E.coli.

\begin{tabular}{lccccc} 
& E.coli & E.coli & E.coli & E.coli & E.coli \\
Actual & $\mathrm{O}_{26}$ & $\mathrm{O}_{55}$ & $\mathrm{O}_{78}$ & $\mathrm{O}_{86}$ & $\mathrm{O}_{111}$ \\
\hline enzyme reactions & & & & & \\
\hline ATP-ase $\%$ & ++++ & +++ & +++ \pm & +++ \pm & ++++ \\
\hline SDH-ase $\%$ & ++++ & +++ \pm & +++ & ++ & ++++ \\
\hline
\end{tabular}

N.B. $\pm=$ traces of enzyme activity, $+=$ week activity, $++=$ submoderate activity, $+++=$ moderate activity, $++++=$ strong activity, $+++++=$ intense enzyme activity.

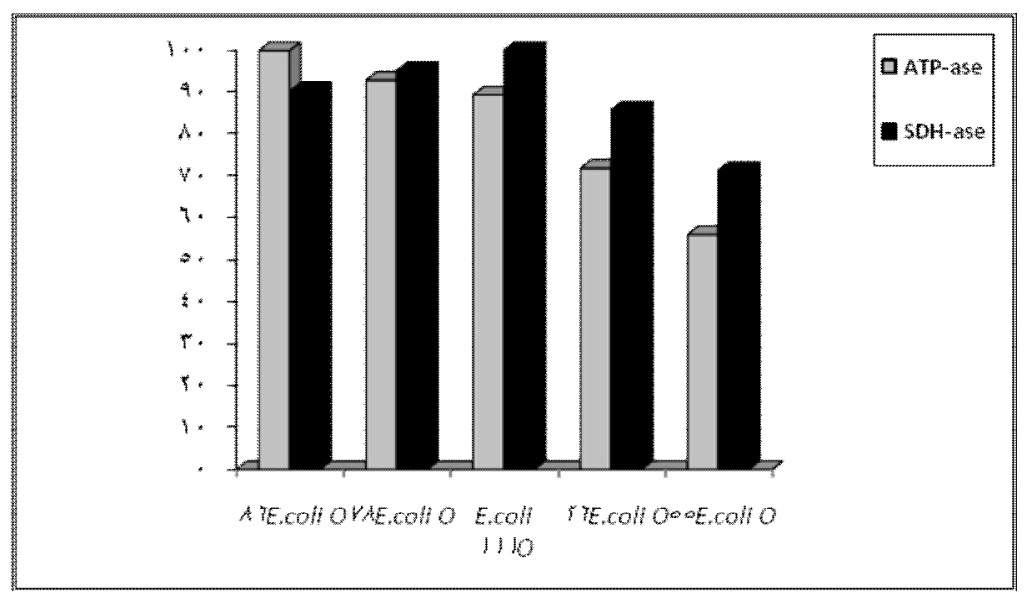

Fig. 1: The reverse relationships between the percentages of the actual reactions of ATP-ase and SDH-ase enzymes of the E.coli serogroups in relation to the higher actual enzyme activities. 


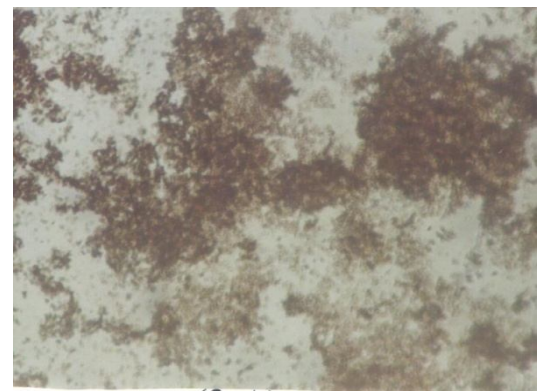

(2-A)

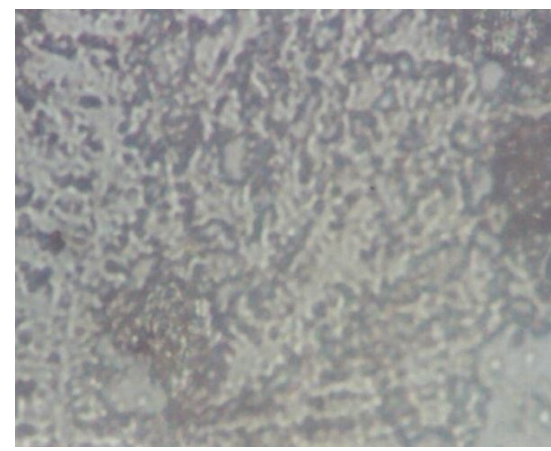

(2-C)

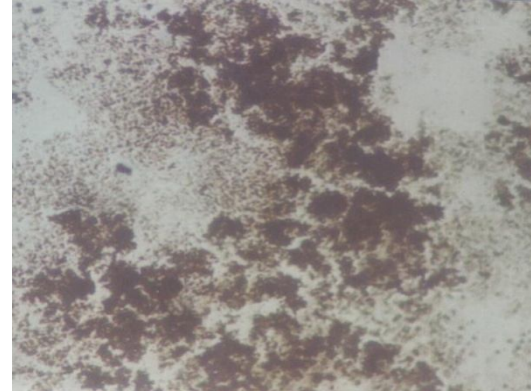

(2-B)

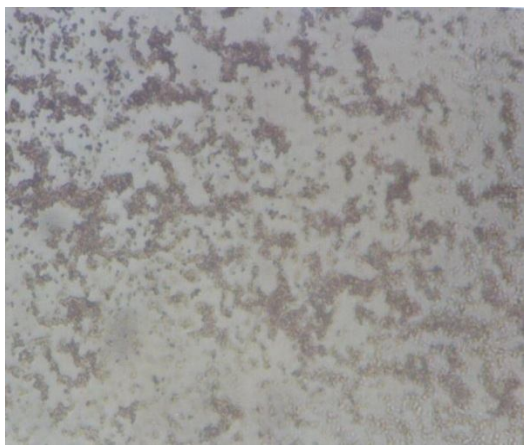

(2-D)

Fig. (2): Showing the activities of ATP-ase and SDH-ase enzymes of the E.coli serogroups after incubation with their substrate media as following:

(2-A): strong tointense (+++++) ATP-ase enzymes activity of the E.coli $\mathrm{O}_{111}$

(2-B): Moderate $(+++)$ ATP-ase enzymes activity of the E.coli $\mathrm{O}_{55}$,

(2-C): strong $(++++)$ SDH-ase enzymes activity of the E.coli $\mathrm{O}_{26}$,

(2-D): Sub-moderate (++) $\mathrm{SDH}$-ase enzymes activity of the E.coli $\mathrm{O}_{86}$

\section{DISCUSSION}

The role of Escherichia coli as a pathogen is well known and many E.coli isolates have been associated with a wide variety of diseases in animals. It's incriminated in production of severe infections such as gastrointestinal colibacillosis, colisepticaemia, hemorrhagic colitis, haemolytic uraemic syndrome, bloody diarrhea and also it is a frequent cause of bovine mastitis. Therefore, increasing attention is being given to the role played by livestock in the epidemiology of this organism and to study biochemical, serological identification and virulence factors in addition to the enzyme cytochemical characterizations. In the present work, from 150 apparently healthy and diarrheic buffalo calves fecal samples $85(56.66 \%)$ were positive for E.coli. In addition, the recovery rates of E.coli isolated from apparently healthy and diarrheic buffalo calves fecal samples were 13 out of $50(26 \%)$ and 72 out of 100 $(72 \%)$ respectively (Table1). These results confirmed that mentioned by Wells et al. (1991) and Karmali et al. (1985) who mentioned that such E.coli strains are mostly and frequently isolated from fecal samples of diarrheic calves. Traditional studies for E.coli were always clarified by referring to the serotyping of the incriminated isolates Orskov and Orskov, (1978). Serogrouping of E.coli was carried out according to the available antisera, 13 serogroups of E.coli were isolated from apparently healthy buffalo calves $\mathrm{O}_{26}(38.46 \%), \quad \mathrm{O}_{111}(23.07 \%), \quad \mathrm{O}_{78}(15.38 \%)$, $\mathrm{O}_{55}(15.38 \%)$ and $\mathrm{O}_{86}(7.69 \%)$ (Table 2); while 72 serogroups of E.coli were isolated from diarrheic buffalo calves $\mathrm{O}_{26}(41.66 \%), \quad \mathrm{O}_{111}(20.83 \%)$, $\mathrm{O}_{78}(19.44 \%), \mathrm{O}_{55}(9.72 \%)$ and $\mathrm{O}_{86}(8.33 \%)$ (Table 3). Table 2 and 3 showed that from apparently healthy and diarrheic buffalo calves $\mathrm{O}_{26}$ serogroup had the highest incidence (38.46\% and $41.66 \%$ respectively), followed by $\mathrm{O}_{111}(23.07 \%$ and $20.83 \%$ respectively). In the same time, $\mathrm{O}_{26}$ and $\mathrm{O}_{111}$ showed nearly the same SDH-ase enzyme activities, as showed by the current cytochemical study and this need further clarification. Many studies have shown that $\mathrm{O}_{26}$ is the most clinically important genotype within the shigatoxin producing E.coli strains isolated from diarrheic and even non diarrheic cases because of its association with bloody and non bloody diarrhea and HUS (Hemolytic ureamic syndrome) Elliott et al. (2001) and Rivas et al. (2006). The virulence factors are thought to play an important role in diseases caused by E.coli, thus the virulence factors of the isolated E.coli serogroups were evaluated in this study.

An overall looking for the present study serotyping of E.coli isolated from apparently healthy and diarrheic buffalo calves fecal isolates as well as a trial to detect the virulence factors aiming to find some 
characteristics that could be depended upon in identifying pathogenic E.coli strains that incorporated in calves diarrhea. In (Table 4), it's clear that 52 isolates were hemolytic with percentage of $61.17 \%$ and belonged to serogroups $\mathrm{O}_{26}(21), \mathrm{O}_{111}(12)$, $\mathrm{O}_{78}(10), \mathrm{O}_{55}(6)$ and $\mathrm{O}_{86}(3)$ a result coordinated with Raji et al. (2003). As well as 26 isolates were positive for enterotoxin production with percentage of $30.58 \%$ belonged to serogroups $\mathrm{O}_{111}(8), \mathrm{O}_{78}(10), \mathrm{O}_{55}$ (5)and $\mathrm{O}_{86}$ (3), enterotoxigenic E.coli colonize the intestine by means of different host Specific Colonization Factors (SCF) and produce one or both of two enterotoxins, the heat stable (ST) and heat labile (LT) toxins which are both able to cause diarrhea Sjoling et al. (2006). While 41 isolates were positive for verotoxin production with percentage of $48.23 \%$ belonged to serogroups $\mathrm{O}_{26}(21), \mathrm{O}_{78}(11), \mathrm{O}_{55}(6)$ and $\mathrm{O}_{86}$ (3). The relatively low incidence of non- $\mathrm{O}_{157}$ verotoxin production alone may not be sufficient for verotoxigenic E.coli to cause disease Barrett et al. (1992). Moreover 48 isolates were positive for invasiveness with percentage of $56.47 \%$ belonged to serogroups $\mathrm{O}_{26}(21), \mathrm{O}_{111}(9), \mathrm{O}_{78}(10), \mathrm{O}_{55}(6)$ and $\mathrm{O}_{86}$ (3), Donnenberg et al. (1989) used HEP-2 cell gentamicin invasion assay to compare the relative invasive ability of enteropathogenic E.coli to enterotoxigenic, enteroinvasive and verocytotoxic E.coli. Finally 56 isolates were positive for Congo red binding activity with percentage of $65.88 \%$ belonged to serogroups $\mathrm{O}_{26}(22), \mathrm{O}_{111}(12), \mathrm{O}_{78}(11)$, $\mathrm{O}_{55}$ (7) and $\mathrm{O}_{86}(4)$, many workers successfully used Congo red binding assay in tryptose soya agar for identification of pathogenic E.coli Roy et al. (2006). By the world health organization as enteropathogenic E.coli or the classical enteropathogenic E.coli were: $\mathrm{O}_{26}, \mathrm{O}_{55}, \mathrm{O}_{86}, \mathrm{O}_{111}, \mathrm{O}_{114}, \mathrm{O}_{119}, \mathrm{O}_{125}, \mathrm{O}_{126}, \mathrm{O}_{127}, \mathrm{O}_{128}, \mathrm{O}_{142}$ and $\mathrm{O}_{158}$ Hernandes et al. (2009). From the all previous results, there were several methods for bacterial identification of the different bacterial species and serotypes, such as biochemical methods Cowan and Steel, (1974), serological Oda et al. (1979), morphological Bailey and Scott, (1990), polymerase chain reaction (PCR) for nucleic acid identification Sambrook et al. (1989). The cytochemical method which should considered as one branch of biochemical method as a recently developing method that firstly described for the purpose of bacterial identification by Rostagi et al. (1984). They could clearly separate the Mycobacterium leprae from certain leprosy derived Corynform bacteria qualitatively. The present study used such cytochemical method through the quantitative determination of some bacterial enzymes in bacterial suspensions with a fixed concentration for the identification or differentiation of the different serogroups of E.coli organisms. The estimation of bacterial ATP-ase and SDH-ase enzyme activities in these serogroups was carried out under the all fixed factors of either cytochemical or bacteriological techniques. Previous trails for quantification of bacterial ATP-ase enzyme activities in E.coli suspension by Bulting et al. (1973). Recently by our trails for differentiation of the different species of Brucella organisms compared with other bacterial species Helal et al. (2011) and more recently for cytochemical differentiation between different strains infecting mammary gland in buffaloes and cattle Helal et al. (2013) through quantitative determination of bacterial ATP-ase and SDH-ase enzyme activities. The quantitative cytochemical enzyme determination were carried out spectrophotometrically or calorimetrically as previously reported by Buttling et al. (1973) and raw, (1975). For the purpose of quantitative cytochemical determination of bacterial enzyme activity in the different bacterial strains, we should fix all cytochemical and bacteriological.

Factors as: culture age before preparing the bacterial suspensions and fresh substrate media for the enzyme reactions (within 3 weeks maximum). For more benefits, the cytochemical method should performed on certain groups of bacteria infecting different body systems, such as bacteria causing enteritis, bacteria causing mastitis, bacteria causing respiratory infections or different serotypes of certain species of bacteria for their close relations in these cytochemical trials. In the previous trial Helal et al. (2011) the bacterial concentration in suspensions of the different bacterial strains was $15 \times 10^{8} \mathrm{CFU} / \mathrm{ml}$ using turbidity standard of McFarland method Quinn et al. (1994) and the incubation period of bacterial suspension with their enzyme-substrate media was $1 \mathrm{hr}$., but in the present study the concentration of bacterial suspension was $5 \times 10^{6} \mathrm{CFU} / \mathrm{ml}$ using spectrophotometer at wave length of $0.750 \mathrm{~nm}$ according to Sarker et al. (2007) for the purpose of accuracy of quantitative estimation, also the incubation period was $1 / 2 \mathrm{hr}$. for saving time. As soon as (within 30 seconds) from adding substrate medium of the enzyme to the bacterial suspension we record the optical density (OD.) of the mixture which was of great importance to recognition of the occurrence of enzymatic reaction after the period of incubation, where the OD. elevated significantly. If no significant elevation of the second OD. reading after incubation, this pointing to failure of enzyme reaction due to presence of significant technical error. The current cytochemical study revealed that the bacterial ATPase activity in the different E.coli serogroups showed non-significant changes between the all serogroups except between E.coli $\mathrm{O}_{55}$ serogroup of lower ATPase activity which could then differentiated it from other studied E.coli serogroups. The Entrohemorrhagic E.coli (EHEC) is the most pathogenic E.coli group which produce shiga-like toxin and cause bloody diarrhea with little or no fever, and if the disease left untreated, it may lead to hemorrhagic colitis as caused by $\mathrm{O}_{26}, \mathrm{O}_{111}, \mathrm{O}_{86}$ and $\mathrm{O}_{78}$, while $\mathrm{O}_{55}$ which is an enteropathogenic E.coli (EPEC) cause watery diarrhea Dobrowsky et al. 
(2013). This indicated that the serogroup E.coliO ${ }_{55}$ is less pathogenic than that of the other studied E.coli serogroups: $\mathrm{O}_{26}, \mathrm{O}_{78}, \mathrm{O}_{86}$ and $\mathrm{O}_{111}$ which of higher ATP-ase than $\mathrm{O}_{55}$ serogroup as there was direct relationship between the bacterial virulence and ATPase enzyme activity. Such virulence property that correlated with higher ATP-ase could be suggested by previous work Helal et al. (2013) in bacteria causing mastitis, where the higher ATP-ase reaction was detected in the more virulent bacteria causing mastitis and vice versa. The ATP-ase enzymes of bacteria include a diverse range of proteins (as pom-z protein) that involved in spatial regulation of bacterium such regulator used for identification of certain types of bacteria Monanhan and Harry, (2012). The significantly similar ATP-ase activity between most E.coli serogroups need another cytochemical assays for their differentiation as SDH-ase enzyme (discussed later), lactic dehydrogenase, glucose-6phosphate gehydrogenase or NADH-diaphorase enzymes determinations for completing figure of enzyme characterizations of the different E.coli serotypes Sheehan and Hrapchak, (1980). Concerning to the succinic dehydrogenase (SDH-ase) enzyme activity, the current study revealed presence of significant variations between SDH-ase enzyme activities among the different E.coli serogroups after incubation period (except between E.coli $\mathrm{O}_{26}$ and E.coli $\mathrm{O}_{111}$ which showed the same SDH-ase activity). The SDH-ase is the only enzyme of the Kreb's cycle that could convert succinate to fumarate Altschal et al. (1996) could use a semi-quantitative cytochemical method for determination of the oxidative enzyme cytochrome-c-oxidase for identification of bacterial species. For more identification and characterization of the different E.coli serogroups by the cytochemical study, the actual enzyme activity (the difference between OD. after and before incubation which calculated for ATPase and SDH-ase enzymes) should be considered. When we arranged the actual ATP-ase reactions from the higher to lower values and then obtaining the percentage of each value (in relation to the higher value) we could obtain different five percentages from $100 \%$ to $56.14 \%$ for the ATP-ase actual reactions and when we compared such percentages of ATP-ase with the corresponding percentages of SDHase of the same bacterial serogroup (Table 8) we could obtain a reversible relationship between ATPase and SDH-ase actual enzyme reactions (Fig.2). Such reversible reactions between the two enzymes were carried out in bacterial mitochondrial membranes as the lack of ATP-ase molecules (due to the activation of ATP-ase enzyme) and the excess of oxaloacetate molecules leading to the suppression of SDH-ase enzyme reactions in bacterial and plant cells indicating the reversible relationships between ATPase and SDH-ase in bacteria (Hung et al., 2010, Helal et al., 2011 and Helal et al., 2013). Based on the present data, the ATP-ase activity could not differentiate between the different E.coli serogroups (except between the serogroup E.coli $\mathrm{O}_{55}$ of the significant lower ATP-ase $(\mathrm{P} \leq 0.05)$ and that of other species, but it could.

Be differentiate between the majority of E.coli serogroups by the significant difference of SDH-ase activity in E.coli serogroups (except between the serogroups E.coli $\mathrm{O}_{26}$ and E.coli $\mathrm{O}_{111}$ which were showed the same SDH-ase activity). Additionally, the values of actual ATP-ase and SDH-ase reactions could be used for differentiation between E.coli serogroups, so that four values for each E.coli serogroup could be used for its characterization and identification are: (OD. of ATP-ase\& actual.

ATP-ase reaction and OD. of SDH-ase and actual $\mathrm{SDH}-$ ase reaction) as an additional tool for bacterial differentiation and identification of E.coli serogroups.

\section{REFERENCES}

Altschal, S.F.; Gish, W.; Miller, W.; Myers, E.W. and Lipman, D.J. (1996): "Basic local alignment search tool." J. Mol. Biol. 215: 403-410.

Andreu, J. M.; Albendea, J. A. and Muñoz, E. (1973): Eur. J. Biochem. 37, 505-515.

Bailey, W.R. and Scott, E.C. (1990): Diagnostic microbiology: a textbook for the isolation and identification of pathogenic microorganisms. C. V. Mosby company. SaintLois.

Barrett, T.J.; Kaper, J.B.; Jerse, A.E. and Wachsmuth, L.K. (1992): Virulence factors in Shiga-like toxin producing Escherichia coli isolated from humans and cattle. Journal of Infectious Diseases 165, 979-980.

Berkhoff, H.A. and Vinal, A.C. (1986): Congo red medium to distinguish between invasive and non-invasive Escherichia coli pathogenic for poultry. Avian Dis.;30(1): 117-121.

Beutin, L.; Montenegro, M.A.; Orskov, I.; Orskov, F.; Prada, J.; Zimmermann, S. and Stephan, $R$. (1989): Close association of verotoxin (Shigalike toxin) production with enterohemolysin in production in strains of Escherichia coli. J. Clin. Microbiol., 27(11): 2559-2564.

Burrows, I. (1985): Textbook of microbiology. $22^{\text {nd }}$ Ed., the C.V. Mosby Company.

Butling, D.; Cox G.B. and Gibson, F. (1973): Oxidative phosphorylation in Escherichia coli $\mathrm{K}-12$ : the genetic and biochemical characterisations of a strain carrying a mutation in the uncB gene. Biochim. Biophys. Acta. Feb. 22; 292(2): 366-375.

Cavalieri, S.J.; Bohach, G.A. and Snyder, I.S. (1984): Escherichia coli alpha-hemolysin: characteristics and probable role in pathogenicity. Microbiol Rev.; 48: 326-343.

Cowan, S.T. and Steel, K.J. (1974): Manual for the identification of medical bacteria, 2nd ed., Cambridge University Press. 
Dobrowksy, P.H.; VanDeventer, A.; Dekwaadsteniet, M.; Ndlovu, T. and Khan, S. (2013): Prevalence of virulence genes associated with pathogenic E.coli strains isolated from domestically harvested rainwater during low and high rainfall periods. Appl. Environ. Microbiol., doi: 10.1128, AEM. 03061-13.

Donnenberg, M.S.; Donohue-Rolfe, A. and Keusch, G.T. (1989): Epithelial cell invasion: an overlooked property of enteropathogenic Escherichia coli (EPEC) associated with the EPEC adherence factor. J. Infect. Dis.;160(3): 452-9.

Elliott, E.J.; Robins-Browne, R.M.; O'Loughlin, E.V.; Bennett-Wood, V. and Bourke, J. (2001): Nation-wide study of haemolytic uraemic syndrome: clinical, microbiological, and epidemiological features. Arch Dis. Child.; 5(2): 125-31.

Giannella, R.A. (1976): Suckling mouse model for detection of heat-stable Escherichia coli enterotoxin: characteristics of the model. Infect. Immun.; 14: 95-99.

Giugliano, L.G.; Mann, G.F. and Drasar, B.S. (1982): Response of mammalian cell lines to the toxins of Escherichia coli. J. Med. Microbiol.;15: 531-539.

Hess, R. and Dietrich, F.M. (1960): Cytochemical localization of dehydrogenase and diaphorase activity in bacillus megaterium. J. Biophys. Biochem. Cytol. 1960 October 1; 8 (2): 546-550.

Helal, A.D.; Hanan, K. Mohmoud and Nahed, M.A. Showky (2013): Bacteriological and cytochemical studies on the relation between some bacteria causing mastitis in buffaloes and its own enzymatic levels. $12^{\text {th }}$ Cong. Egyptian Society for Cattle Diseases, 3-6Dec., 2013, Hurgada, Egypt.

Helal, A.D.; Khoudair, M. Ramdan and Karaitam, Kh.M. (2011): Trial for identification of the different strains of brucella compared with other bacterial species using the quantitive cytochemical determination of some mitochondrial enzymes. Mansora Vet. Med. J. (2): 201-223.

Hernandes, R.T.; Elias, W.P.; Vieira, M.A.M. and Gomes, T.A.T. (2009): An overview of atypical enteropathogenic Escherichia coli. FEMS Microbiology Letters. 292: 137-149.

Hung, S.; Tylor, N.L.; Narsai, R.; Eubel, H.; Whelon, J. and Millor, A.H. (2010): Functional and composition difference between mitochondrial complex II in Arabidopsis and rice are correlated with the complex genetic history of the enzyme. Plant. Mol. Biol., 72(3): 331-342.

Janda, J.M. and Abbott, S.L. (1998): The Enterobacteria. A hand book. Library of Congress. pp.13-65.
Janke, B.H.; Francis, D.H.; Collins, J.E.; Libal, M.C.; Zeman, D.H.; Johnson, D.D. and Neiger, R.D. (1990): Attaching and effacing Escherichia coli infections as a cause of diarrhea in young calves. JAVMA.; 196(6): 897-901.

Karmali, M.A.; Petric, M.; Lim, C.; Fleming, P.C; Arbus, C.S. and Lior, H. (1985): The association between idiopathic hemolytic uremic syndrome and infection by verotoxinproducing Escherichia coli. J. infect. Dis., 151; 775-782.

Koneman, E.W.; Allen, S.D.; Dawel, V.P. and Sommers, H.M. (1997): Color atlas and text book of diagnostic microbiology. $2^{\text {rd }} \mathrm{Ed}$. Lippincott, Philadelphia, NewYork, London.

Monanhan, L.G. and Harry, E.J. (2012): Identifying how bacterial cells find their middle: a new perspective. PMID: 23190137.

Nachlas, M.M.; Tsou, K.C.; D.E. Souza E, Cheng, CS, Seligman, A.M. (1957): Cytochemical demonstration of succinic dehydrogenase by the use of a new p-nitrophenyl substituted ditetrazole. J. Histochem Cytochem. Jul; 5(4): 420-436.

Oda, T.; Okkubo, T.; Nagai, M.; Nishimoto, Y. and Ohma-ruk, K. (1979): "Detection of Staphylococcal enterotoxins in foods by reversed passive latex aggulitination test." Ann. Rep. Fukuaka City, Hyg. Lab. 4: 33.

Orskov, F. and Orskov, I. (1978): Serotyping of Enterobacteriaceae with special emphasis on $\mathrm{K}$ antigen determination methods in Microbiology, edit by Bergan, T. and Norris, J.R. Acad. Press, London, 11,1-77.

Paul, S.K.; Khan, M.S.R.; Rashid, M.A.; Hassan, J. and Mahmud, S.M.S. (2010): Isolation and characterization of Escherichia coli from buffalo calves in some selected areas of Bangladesh. Bangl. J. Vet. Med. , 8(1): 23-26.

Pearse, A.G.E. (1972): Histochemistry, theoretical and applied. Vol. (2). London, Churchill Livingstone.

Quinn, P.J.; Carter, M.E.; Markey, B.K. and Carter, G.R. (1994): Clinical. Veterinary Microbiology. Mosby year book Europe limited, Linton House. London, PP: 109-126.

Radostits, O.M.; Blood, D.C. and Gay, C.C. (1994): Diseases by inorganic and farm chemicals. Veterinary medicine. VII edition, Bailliere Tindall London, Uk.

Raji, M.A.; Adekeye, J.O.; Kwaga, J.K.P. and Bale, J.O.O. (2003): In vitro and in vivo pathogenicity studies of Escherichia coli isolated from poultry in Nigeria. Israel Journal of Veterinary Medicine. Vol. 58 (1).

Rana, N.; Raut, A.A.; Khurana, S.K.; Manuja, A. and Saini, A. (2012): Isolation and biotyping of Salmonella and Escherichia coli associated 
with neonatal buffalo calves. The Indian Journal of Animal Sciences, 82(7): 676-678.

Rivas, M.; Miliwebsky, E.; Chinen, I.; Roldan, C.D. and Balbi, L. (2006): Characterization and epidemiologic subtyping of Shiga toxinproducing Escherichia coli strains isolated from hemolytic uremic syndrome and diarrhea cases in Argentina. Foodborne Pathog. Dis.; 5(1): 88-96.

Robins-Browne, R.M.; Takeda, T.; Fasano, A.; Bordun, A.M.; Dohi, S.; Kasuga, H.; Fang, G.; Prado, V.; Guerrant, R.L. and Morris J.G. Jr. (1993): Assessment of enterotoxin production by Yersinia enterocolitica and identification of a novel heat-stable enterotoxin produced by a non invasive $Y$. enterocolitica strain isolated from clinical material. Infect. Immun. 61: 764-767.

Rostagi, N.; Frehel, C. and David, H.I. (1984): Cell envelope architeetures of leprosy derived Corynbacterium, Mycobacterium leprae and related organisms a comparative study. Curs Microboil (11): 23-30.

Roy, P.; Purushothaman, V.; Koteeswaran, A. and Dhillon, A.S. (2006): Isolation, characterization and antimicrobial drug resistance pattern of Escherichia coli isolated from Japanese quail and their environment. J. Applied Poult. Res., 15: 442-446.

Sambrook, J.; Fritish, E.F. and Maniatis, T. (1989): Molecular Cloning. A Laboratory Manual, $2^{\text {nd }}$ Ed. Cold Spring Harbor, NY: Cold Spring Harbor Laboratory Press.

Sarker, S.D.; Lutfun Nahar, B. and Kumarasamy, Y. (2007): Microtiter plate-based antibacterial assay incorporating resazurin as an indicator of cell growth and its application in the in vitro antibacterial screening of phytochemicals. Methods (42): 321-324.

Sheehan, D.C. and Hrapchak, B.B. (1980): Theory and practice of histotechnology, enzymehistochemistry, chapter(17), The C.V. Mosby, St. Louis, Toronto, London.

Sjoling, A.; Qadri, F.; Nicklasson, M.; Begum, Y.A.; Wiklund, G. and Svennerholm, A.M. (2006): In vivo expression of the heat stable (estA) and heat labile (eltB) toxin genes of enterotoxigenic Escherichia coli (ETEC). Microbes Infect.; 8(12-13): 2797-802.

Snedecor, G.W. and Cochran, W.G. (1969): Statistical Methods. $6^{\text {th }}$.The Iowa State college press, Ames, Iowa

Tevejo, R.T.; Barr, M.C. and Robinson, R. A. (2005): Important emerging bacterial zoonotic infections affecting the immunocompromised. Vet. Res. 36, 493-506.

Wachstein, M. and Meisel, E. (1957): Histochemistry of hepatic phosphatases at a physiologic $\mathrm{pH}$ with special reference to the demonstration of bile canaliculi.Amer. J. clin.Pathol. 27: 13-23.

Wells, J.G; Shipman, L.D.; Green, K.D.; Sowers, E.G.; Cameron, D.B; Downes, F.P; Martin, M.L.; Griffin, P.M.; Ostroff, S.M.; Potter, M.E.; Taux R.W. and Wachsmath, I.K. (1991): Isolation of Escherichia coli serotype O157:H7 and other shiga like toxin producing E.coli from dairy cattle. J. Clin. Microbial., 29(5): 985-989.

Zaman, T.; Khan, A. and Akhtar, M.Z. (2006): Some of the risk factors of buffallo (Bubalusbubalis) neonatal calf mortality in Pakistan. Pakistan Vet. J., 2006, 26(3): 121-125.

\title{
استخدام الطرق التقليدية والسيتوكيميائية الكمية للتعرف على بعض العترات السيرولوجية للميكروب القولوني المسببة

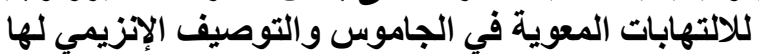

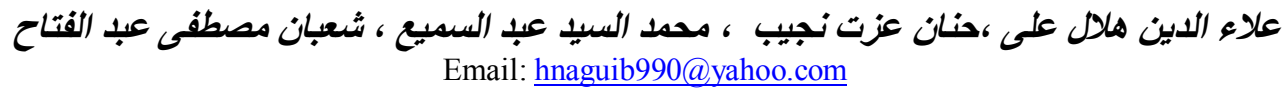

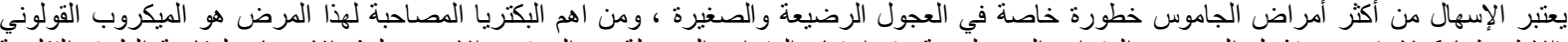

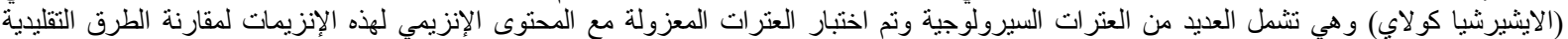

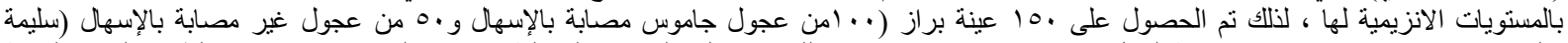

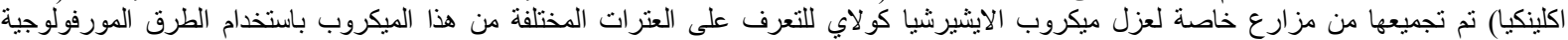

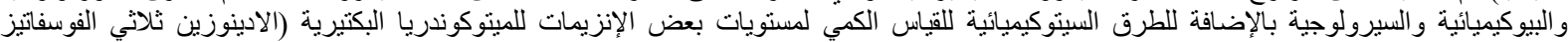

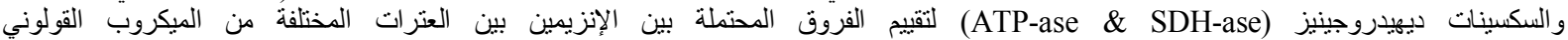
(E.coli-serogroupes)

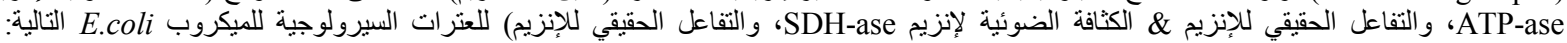

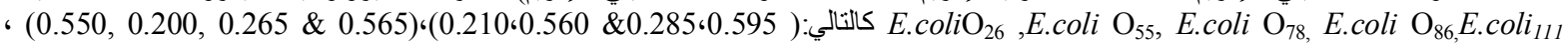

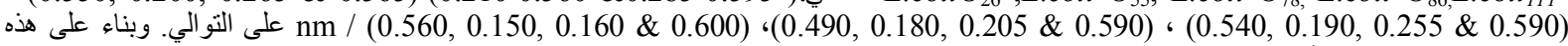

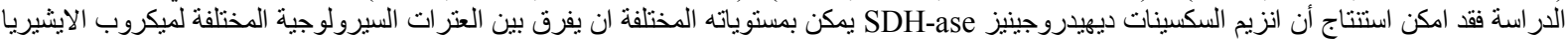

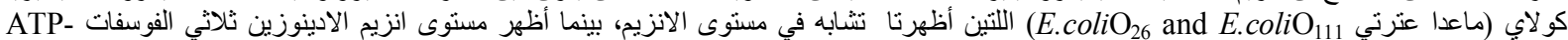

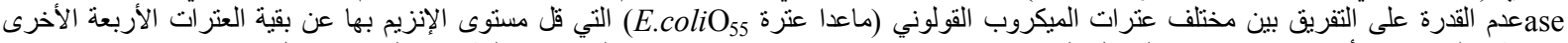

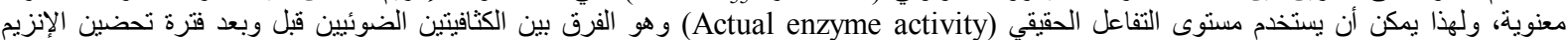

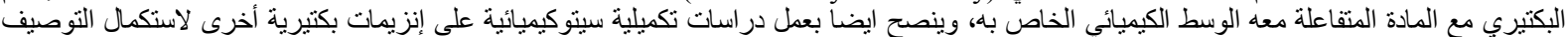

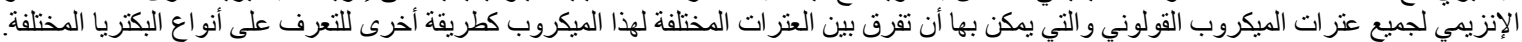

